\title{
Studi Literasi Menggunakan Endnote Dan Aplikasi Pembantu (Google Translator, Google Cendikia, Google Sites, Chemoffice 2008, e-learning, dan Snipping Tool)
}

\author{
Dr Rahadian Zainul, S.Pd., M.Si \\ Jurusan Kimia, FMIPA, Universitas Negeri Padang
}

\begin{abstract}
ABSTRAK
Sains berkembang dengan metoda ilmiah. Salah satu produknya berupa artikel ilmiah yang disusun dengan menggunakan endnote, dan aplikasi pembantu seperti google translator, Chemoffice 2008, google cendikia dan snipping tool. Dalam produknya akan tergambar Pendahuluan, Ekperimental, Hasil-Pembahasan dan Kesimpulan serta referensi. Skill (Keahlian) dan kemampuan membaca, menganalisa dan mengolah informasi secara integralistik merupakan muara dari Studi literasi yang mesti dimiliki setiap mahasiswa sains sedari awal. Dalam Wikipedia, Literasi itu mencakup computer literacy, library skill dan critical thingking. Artikel ini bertujuan bagaimana skill mendasar tersebut dapat dikembangkan dan dilatih bagi mahasiswa baru Pendidikan IPA FMIPA Universitas Negeri Padang.
\end{abstract}

Kata Kunci : Literasi, Endnote, Google Translator, Google Sites, Google Cendikia, Chemoffice 2008, e-learning, Snipping Tool

\section{PENDAHULUAN}

Literasi adalah kemampuan untuk membaca, menulis, dan menggunakan aritmatika. Lebih luas, literasi untuk mencakup kemampuan untuk menggunakan bahasa, angka, gambar, komputer, dan sarana dasar lainnya untuk memahami, berkomunikasi, memperoleh ilmu yang bermanfaat. Konsep literasi berkembang memasukkan keterampilan untuk mengakses pengetahuan melalui teknologi dan kemampuan untuk menilai konteks yang kompleks.

Kunci untuk literasi adalah kemampuan membaca yakni keterampilan yang diawali dengan kemampuan untuk menterjemahkan kalimat (kata-kata), menulis kembali kalimat (katakata) tersebut, dan akhirnya memahami konsep. "Membaca", berarti mengetahui bunyi (fonologi), pola ejaan (ortografi), arti kata (semantik), tata bahasa (sintaks) dan pola pembentukan kata (morfologi). Dari proses inilah orientasi, eksplorasi, pembentukan konsep (pemahaman) dan aplikasi dapat terbentuk.

Setelah keterampilan ini diperoleh, mahasiswa dapat menghasilkan karya yang kritis (analisis), membuat kesimpulan (sintesis); menulis dengan akurasi (koherensi); dan untuk menggunakan informasi dan wawasan dari teks sebagai dasar untuk keputusan dan pemikiran kreatif. 
UNESCO mendefinisikan Literasi sebagai "kemampuan untuk mengidentifikasi, memahami, menafsirkan, membuat, berkomunikasi dan menghitung, menggunakan dan menulis bahan yang terkait dengan konteks yang berbeda-beda. Literasi melibatkan kontinum belajar dalam memungkinkan individu untuk mencapai tujuan mereka, untuk mengembangkan pengetahuan dan potensi mereka, dan untuk berpartisipasi penuh dalam komunitas mereka dan masyarakat yang lebih luas".

Literasi informasi merupakan kemampuan yang sangat diperlukan dalam memenuhi kebutuhan seseorang. Dalam memenuhi kebutuhan tersebut terdapat beberapa kriteria dalam literasi informasi. Menurut Pendit (2007:7) bahwa terdapat 7 (tujuh) keterampilan yang dibutuhkan dalam era digital yaitu Tool literacy: kemampuan memahami dan menggunakan teknologi informasi secara konseptual dan praktikal, termasuk di dalamnya kemampuan menggunakan perangkat lunak, keras, multimedia yang relevan dengan bidang kerja atau studi. Resources literacy;: kemampuan memahami bentuk, format, lokasi, dan cara mendapatkan sumber daya informasi terutama jaringan informasi yang terus berkembang

Social structural literacy; Pemahaman tentang bagaimana informasi dihasilkan oleh berbagai pihak di dalam sebuah masyarakat. Research literacy; Kemampuan menggunakan peralatan berbasis teknologi informasi sebagai alat riset. Publishing literacy; Kemampuan untuk menyusun dan menerbitkan publikasi dan ide ilmiah ke kalangan masyarakat dengan memanfaatkan komputer dan internet.

Emerging technology literacy ; Kemampuan yang memungkinkan seseorang untuk terus menerus menyesuaikan diri dan mengikuti perkembangan tekhnologi dan bersama-sama dengan komunitasnya ikut menentukan arah pemanfaatan tekhnologi informasi untuk kepentingan pengembangan ilmu. Critical literacy ; Kemampuan melakukan evaluasi secara kritis terhadap untung rugi menggunakan teknologi telematika dalam kegiatan ilmiah.

Dalam artikel ini, bagaimana menggunakan menggunakan endnote, dan aplikasi pembantu (google) untuk mengorganisasi bahan bahan dan informasi yang ada untuk mendapatkan ide ide ilmiah serta mengembangkannya menjadi produk literasi sains dan kreatif, baik dalam bentuk teknologi maupun publikasi ilmiah.

\section{EKPERIMENTAL}

\section{BAHAN DAN PROSEDURAL}

Software yang digunakan Endnote X7 Thomson Reuters, Google Translator, Google Cendikia, Chemoffice 2008 Cambridgesoft, Snipping Tool dan aplikasi lain. Aplikasi ini diinstalkan pada Windows XP atau Vista, yang lebih ringan dan biasanya berjalan dengan baik untuk beberapa aplikasi. Pada Windows terbaru, Windows 8 dan 10, beberapa aplikasi membutuhkan versi update dan lebih berat untuk dijalankan. 
Prosedur yang dilakukan adalah instalasi dan koneksi jaringan internet sehingga memungkinkannya 'surfing' data berjalan lebih cepat. Proses instalasi dilakukan dengan cara membuka file aplikasi (EXE) dan seterusnya mengikuti proses instalasi sebagaimana biasanya, yakni tekan NEXT dan pilih sesuai petunjuk dan perintahnya. Apabila proses instalasi selesai, maka software atau aplikasi sudah bisa dijalankan. Pada aplikasi pembantu, seperti Google Translate, google map, google cendikia, dan snipping tool sudah tersedia pada komponen bawaan pada Google dan Windows, untuk mengaktifkannya sesuai dengan pilihan sebagaimana mestinya seperti terlihat pada gambar 1 .

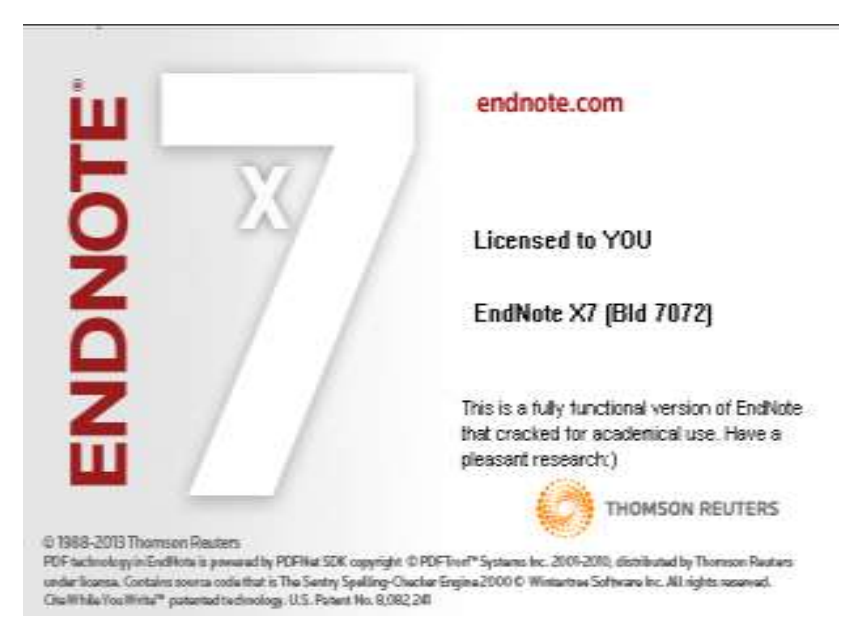

(a)

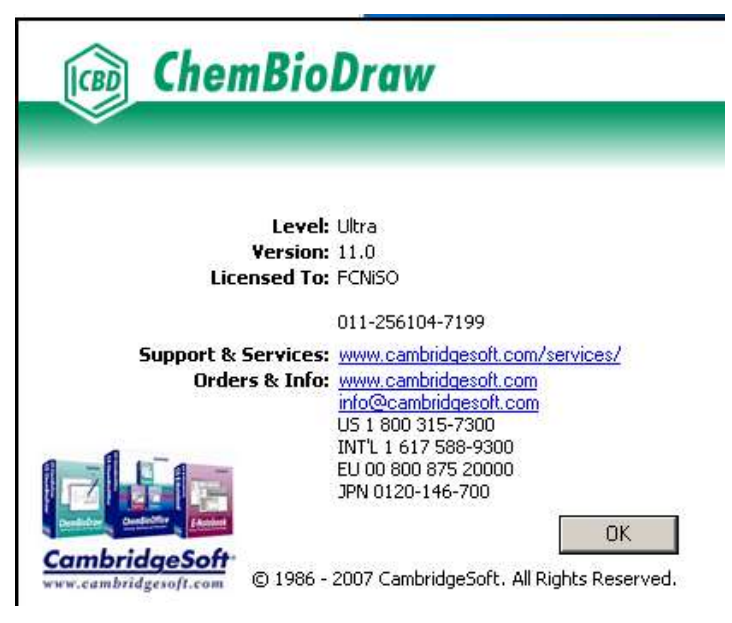

(b)

Gambar 1. Tampilan awal software endnote (a) dan CambridgeSoft (b)

Setelah instalasi selesai, maka proses literasi sduah dapat dilakukan dengan tahapan awal yakni menjalankan endnote seperti terlihat pada gambar 2.

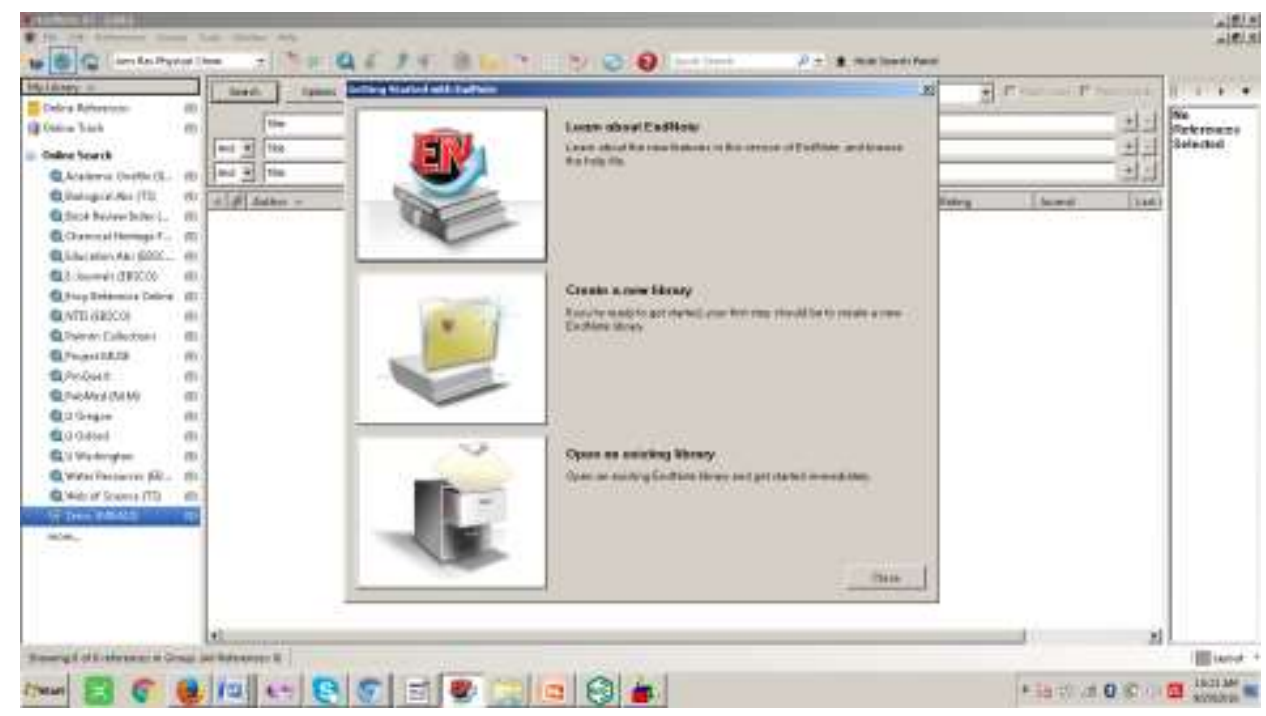

Gambar 2. Program endnote saat dijalankan untuk tujuan literasi

Dr Rahadian Zainul, S.Pd., M.Si. 
Langkah awal dalam proses literasi adalah memutuskan ide dan persoalan yang akan dibahas melalui kata kunci (keywords). Tanpa keywords, penggunaan internet akan mengambang dan tidak efisien. Dengan penggunaan Endnote X7, proses identifikasi keyword membutuhkan waktu 1 detik, tidak jauh beda dengan menggunakan penjelajah google. Misalnya, pada proses pencarian keyword "BIOLOGY" dengan google cendikia, membutuhkan waktu 0.04 detik dengan jumlah temuan 5.260.000. Sementara, bila menggunakan ENDNOTE X7, memerlukan waktu 0.5 detik dengan temuan 1.347.502 literatur pada Pustaka Dunia PubMed (NLM) seperti terlihat pada gambar 3 .

\section{Web Gambar Lainnya..}

Google

$$
\text { biology }
$$

Sekitar 5.260.000 hasil (0,04 dtk)

Cendekia

(a) Penjelajahan Google Cendikia

$\begin{array}{lr}\text { QE-Journals (EBSCO) } & (0) \\ \text { Q Ency Britannica Online } & (0) \\ \text { QNTIS (EBSCO) } & (0) \\ \text { Q Palmm Collections } & (0) \\ \text { Q ProjectMUSE } & (0) \\ \text { Q ProQuest } & (0) \\ \text { C. PubMed (NLM) } & (0)\end{array}$

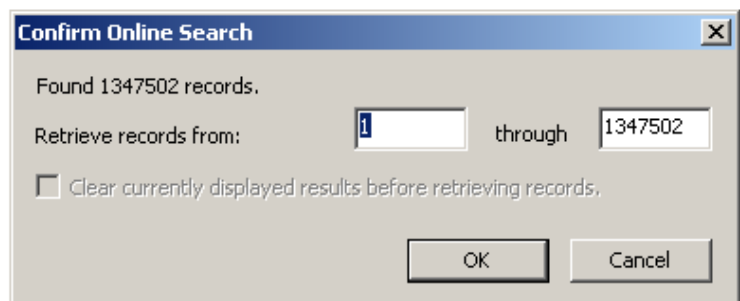

(b) Penjelajahan Endnote X7

\section{Gambar 3. Penjelajahan Google Cendikia dan Endnote 7}

Penjelajahan Google Cendikia lebih bersifat umum, sementara penjelajahan menggunakan Endnote7 lebih spesifik. Pada kasus di atas, endnote digunakan untuk menjelajah pada Web Pubmed(NLM) yang menyediakan lebih dari 26 juta citation untuk bidang biomedik, baik berupa jurnal maupun buku. Ada ribuan perpustakaan di dunia yang terintegrasi pada endnote X7, tetapi tidak semua bisa diakses. Bagi mahasiswa Pendidikan IPA FMIPA bisa akses juga secara free di JOHNS HOPKINS UNIVERSITY dan ENCYCLOPEDIA BRITANICA.

Pada Universitas Negeri Padang, tersedia akses pada Proquest, EBSCO dan IET. Pada Proquest, http : //search.proquest.com, dengan username : 08wgm8377g dan password : PQUNP\#1padang. Kemudian, IET digital Library (The Institution of Engineering and Technology), dengan URL : http ://www.ietdl.org. Terakhir, pada EBSCO dengan alamatnya http://search.ebscohost.com/ ; http://m.ebscohost.com ; http://search.ebscohost.mobi, dengan Username : ns180943 dan Password : password. Situs situs ini dapat diakses secara free oleh 
seluruh civitas akademikia Universitas Negeri Padang, dan menurut informasi, UNP membayar mahal untuk bisa mengakses secara free pada situs situs jurnal dan literasi ini.

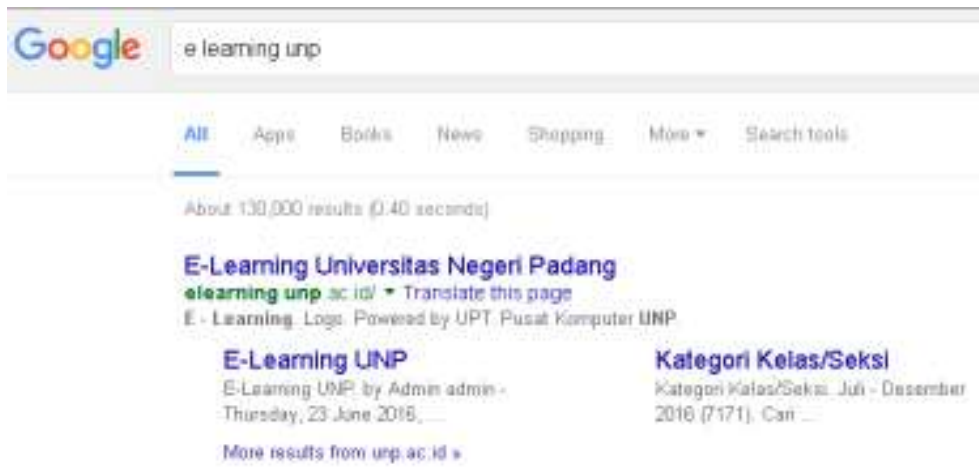

(a) E-learning Universitas Negeri Padang

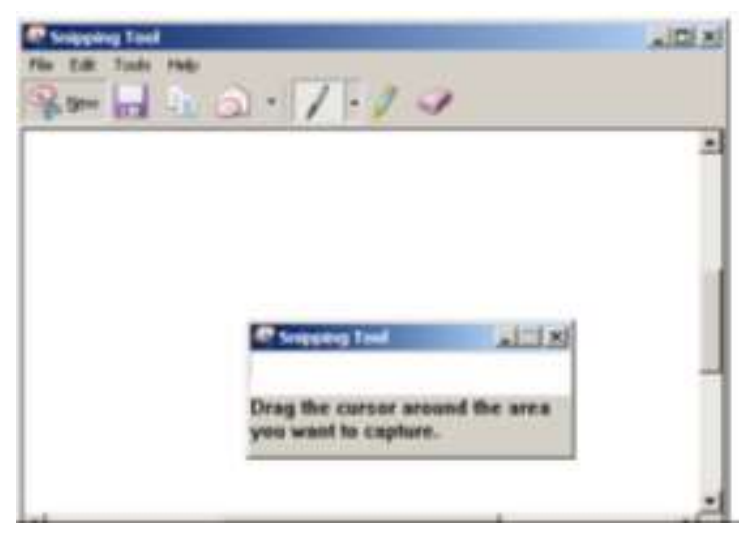

(b) snipping tool

\section{Google}

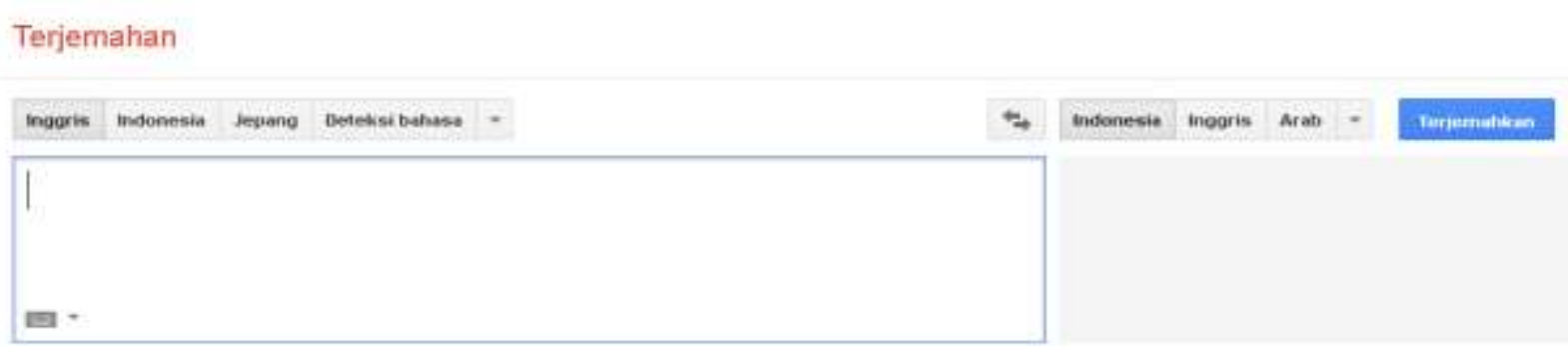

(c) Google Translator atau google terjemahan

Gambar 4. E-learning Universitas Negeri Padang (a) dan Aplikasi pada google yang dapat membantu proses literasi (b, c)

Pemakaian e-learning dan aplikasi google seperti terlihat pada gambar 4, dapat membantu studi literasi mahasiswa baru Jurusan Pendidikan IPA FMIPA. Hal ini membantu dalam mengorganisasi, menganalisis dan mengembangkan perkuliahan sehingga dapat meningkatkan kemampuan mahasiswa dalam proses perkuliahan terutama dalam kaitannya dengan tugas tugas mata kuliah dan tugas akhir (skripsi).

\section{HASIL DAN PEMBAHASAN}

\section{Penggunaan Endnote X7(1-22)}

Software Endnote X7 dikeluarkan oleh Thomson Reuters untuk kepentingan scientist di seluruh dunia, sejak tahun 1988-2013. Pengembangan software adalah PDFTron System Inc, dan didistribusikan Thomson Reuters dibawah lisensi. Software ini diaplikasikan untuk Penjelajah Literatur dan Jurnal jurnal yang terindex, Pembuatan Library Digital dan Penyusunan Literatur 
sesuai standar ilmiah dan internasional, berdasarkan Universitas universitas Ternama di Dunia (Harvard, Vancouver, etc) dan Lembaga keilmuan bereputasi (American Chemical Society/ACS, Acta Biomaterialia, Ann Rev Biophysics, etc).

Pembuatan library digital dilakukan dengan menentukan nama library, bisa berdasarkan nama personal, atau berdasarkan objek kajian/bahasan. Library bila dibuat dalam skala besar dilakukan untuk Main Topik, misalnya mata kuliah. Jika dilakukan untuk tujuan paper, maka library sesuai dengan tematik paper yang dibuat. Secara sederhana, pada BAR, pilih NEW, lalu masukkan NAMA LIBRARY yang diinginkan, dan PILIH LOKASI atau FOLDER sesuai dengan penyimpanan data seperti pada gambar 5.

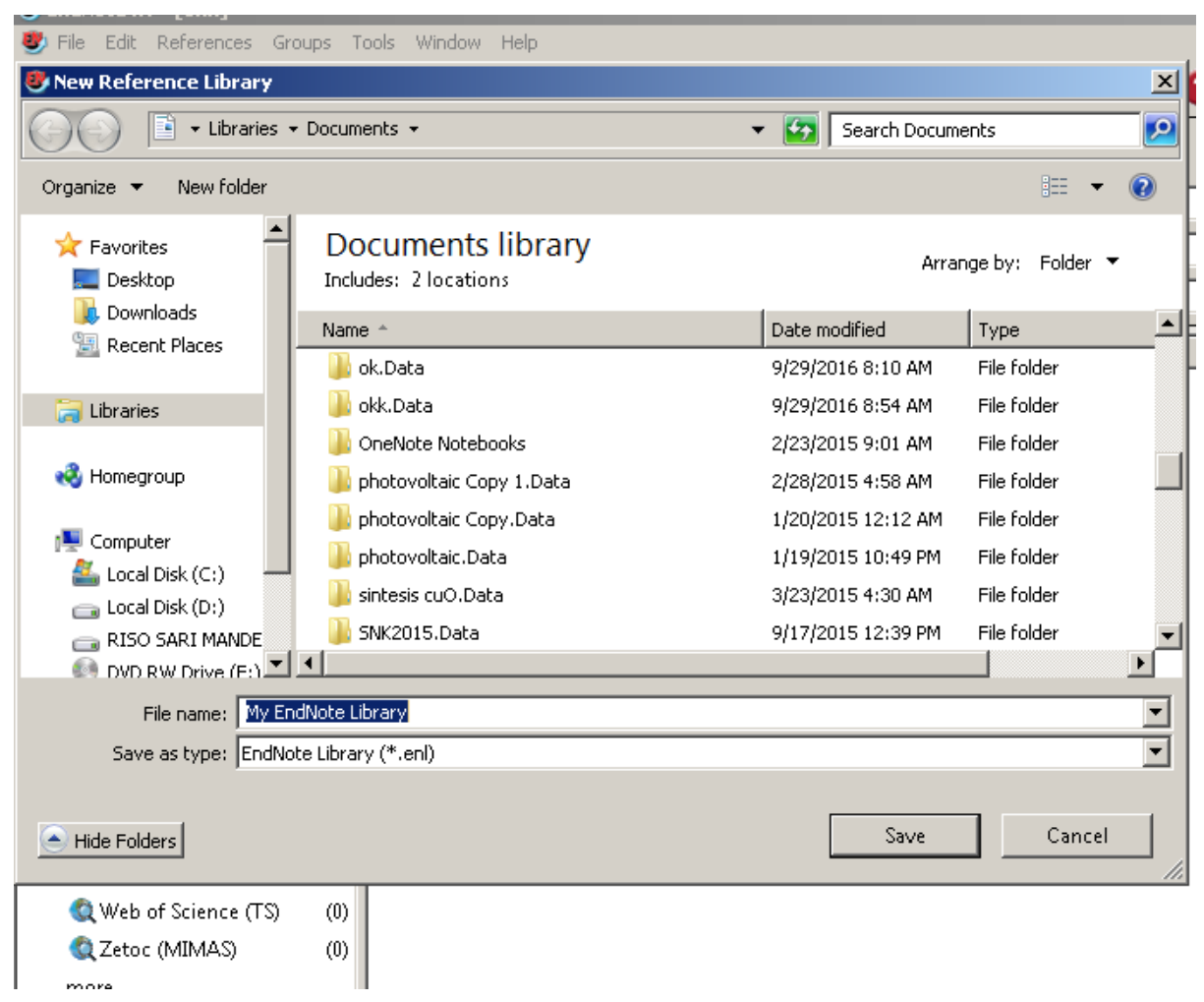

Gambar 5. Pembuatan LIBRARY pada Endnote X7

Penjelajahan literasi menggunakan endnote X7, dapat dilakukan dengan menentukan perpustakaan yang akses. Beberapa Universitas besar dan ternama di dunia, tidak memberikan akses kecuali bagi mahasiswa mereka sendiri atau pihak lain yang diberikan lisensi berupa Username dan password. Universitas Oxford di Inggris, Universitas Adelaide, dan beberapa universitas di Amerika Serikat tidak menyediakan akses kepada pengguna luar seperti pada gambar 6. Akses koneksi ini membutuhkan jaringan internet dan izin koneksi internal pada Perpustakaan Dunia yang akan diakses. Akses yang cukup memadai dapat dilakukan pada 
Universitas Johns Hopkins, di Baltimore, Maryland, Amerika Serikat, berdiri sejak 1876. Universitas ini menyediakan akses free bagi penjelajah penjelajah literasi dunia.

Begitu juga Perpustakaan ENCYCLOPEDIA BRITANICA, juga memberikan akses free. Encyclopedia Britanica Inc, merupakan ensiklopedia tertua di dunia yang berada di Inggris, yang dirilis 1768-sekarang. Perpustakaan yang lain adalah Pubmed (NLM) yang menyediakan lebih dari 26 juta manuskrip yang bisa diakses dan didownload untuk membuat perpustakaan personal dan disitasi untuk keperluan pembuatan karya ilmiah dan studi literature ilmiah.

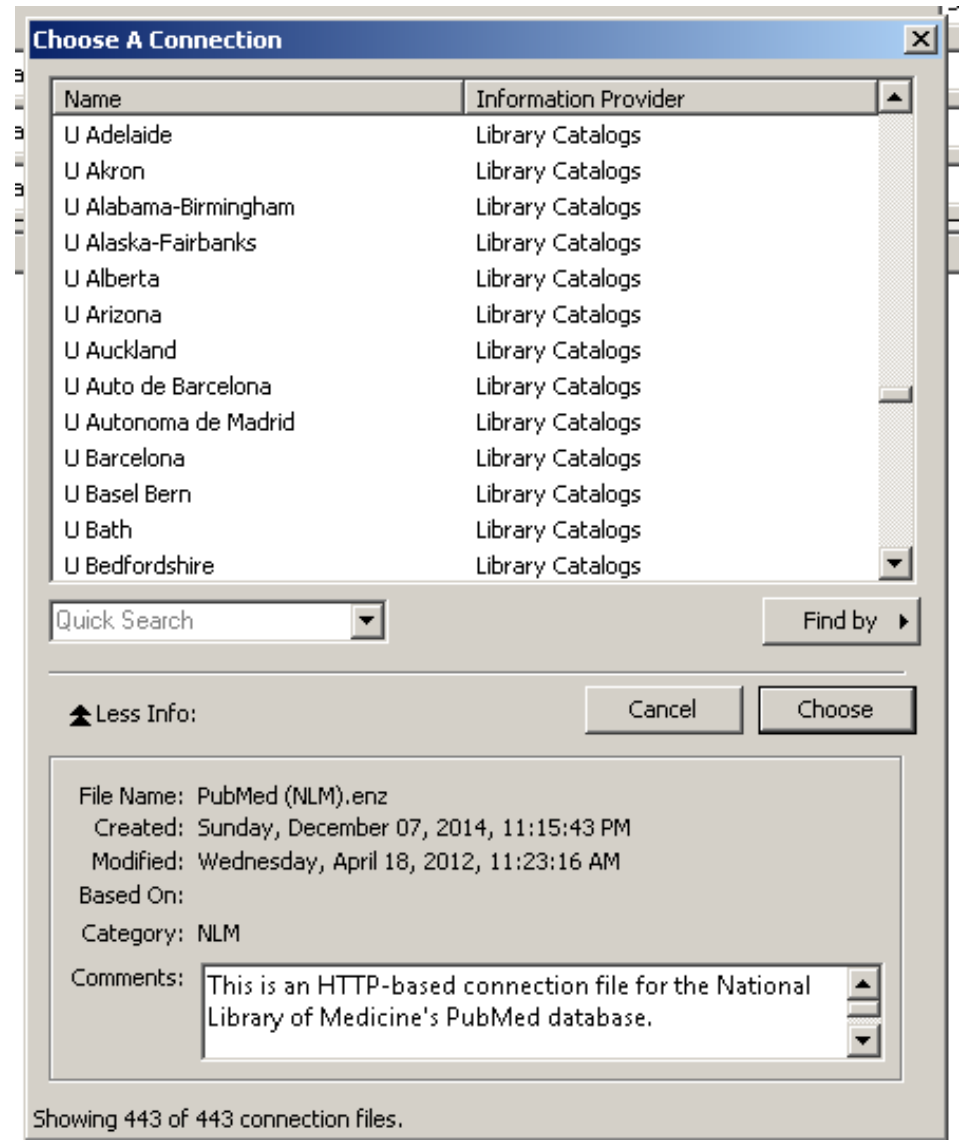

Gambar 6. Beberapa akses yang terblokir pada beberapa Universitas Dunia

Pembuatan REFERENSI dilakukan dengan mentrasnform atau menyimpan hasil pencarian ke dalam bentuk referensi. Langkah berikutnya adalah melakukan pencarian FULL TEXT dari literature yang digunakan secara otomatis dan tersimpan secara rapi pada LIBRARY yang telah dibuat. Apabila semua file sudah tersimpan, maka untuk membuat REFERENSI atau kutipan pada bagian yang diperlukan dari bahan bahan yang diakses tersebut, koneksi online tidak diperlukan. Pada saat penyusunan artikel atau karya ilmiah, maka akses literature secara terintegrasi tergabung pada MICROSOFT WORD. Hal ini memudahkan untuk menandai bagian 
bagian Studi PUSTAKA yang dijadikan referensi dari sebuah karya ilmiah seperti terlihat pada gambar 7.

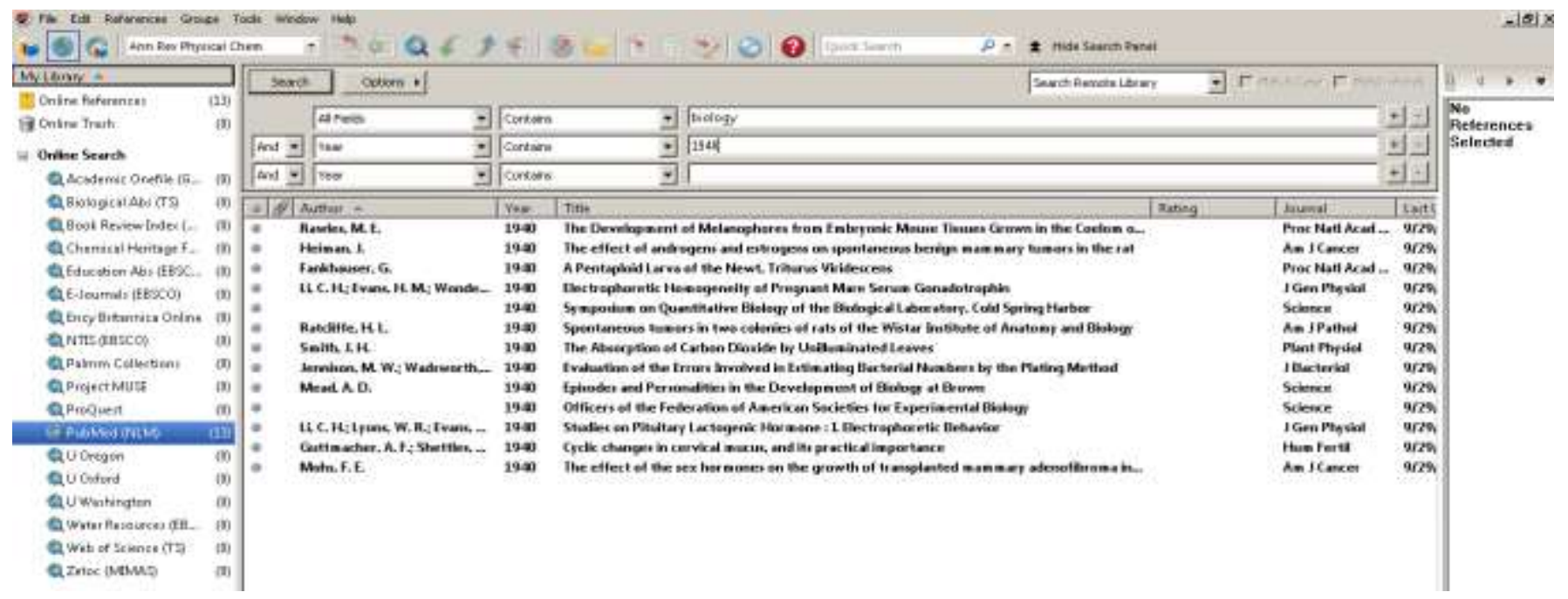

Gambar 7. Penjelajahan Endnote X7 untuk keyword BIOLOGY pada Pubmed

Pada gambar 7 terlihat beberapa kolom yang bisa membantu proses penjelajahan menjadi efisien dan efektif. Pada gambar, proses pencarian dibatasi dengan YEAR atau tahun yakni 1940. Hasilnya adalah pada tahun 1940 terdapat 13 buah manuskrip yang tersimpan pada perpustakaan PubMed yang bisa diakses dan diambil secara gratis. Proses selanjutnya adalah memindahkan atau mengcopy hasil penjelajahan ke dalam LIBRARY personal dengan cara select dengan drag sehingga semua hasil pencarian terwarnai, lalu pada BAR pilih REFERENCES dan COPY REFERENCES TO, pilih NEW (jika belum ada) atau pilih CHOOSE (bila sudah ada). Jika selesai, maka selanjutnya lakukan langkah jelajah FULL TEXT.

Keunggulan ENDNOTE X7 adalah aplikasi ini sudah terintegrasi dengan MICROSOFT WORD, sehingga kutipan yang dilakukan dapat diakses dengan mudah dan penandaannya dilakukan secara otomatis dengan pilihan sebagai berikut. Aktifkan BAR Endnote, lalu buka LIBRARY, dan selanjutnya drag bagian yang akan menjadi kutipan pada ENDNOTE. Pindah Kerja ke MICROSOFT WORD, lalu aktifkan BAR ENDNOTE pada WORD seperti terlihat pada gambar 8 .

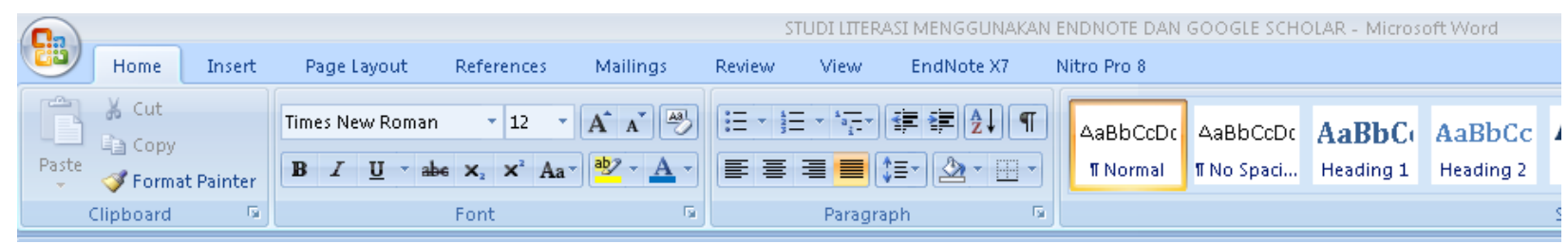

Gambar 8. Bar ENDNOTE pada Microsoft Word, pada posisi belum aktif

Dr Rahadian Zainul, S.Pd., M.Si. 
Selanjutnya, aktifkan BAR endnote dan tampilan akan berubah seperti gambar 9. Lalu, pilih BAR kiri atas, INSERT CITATION, lalu pilih selected citation, dan tekan ENTER. Maka secara otomatis, citasi akan masuk pada dokumen word yang sedang dibuat.

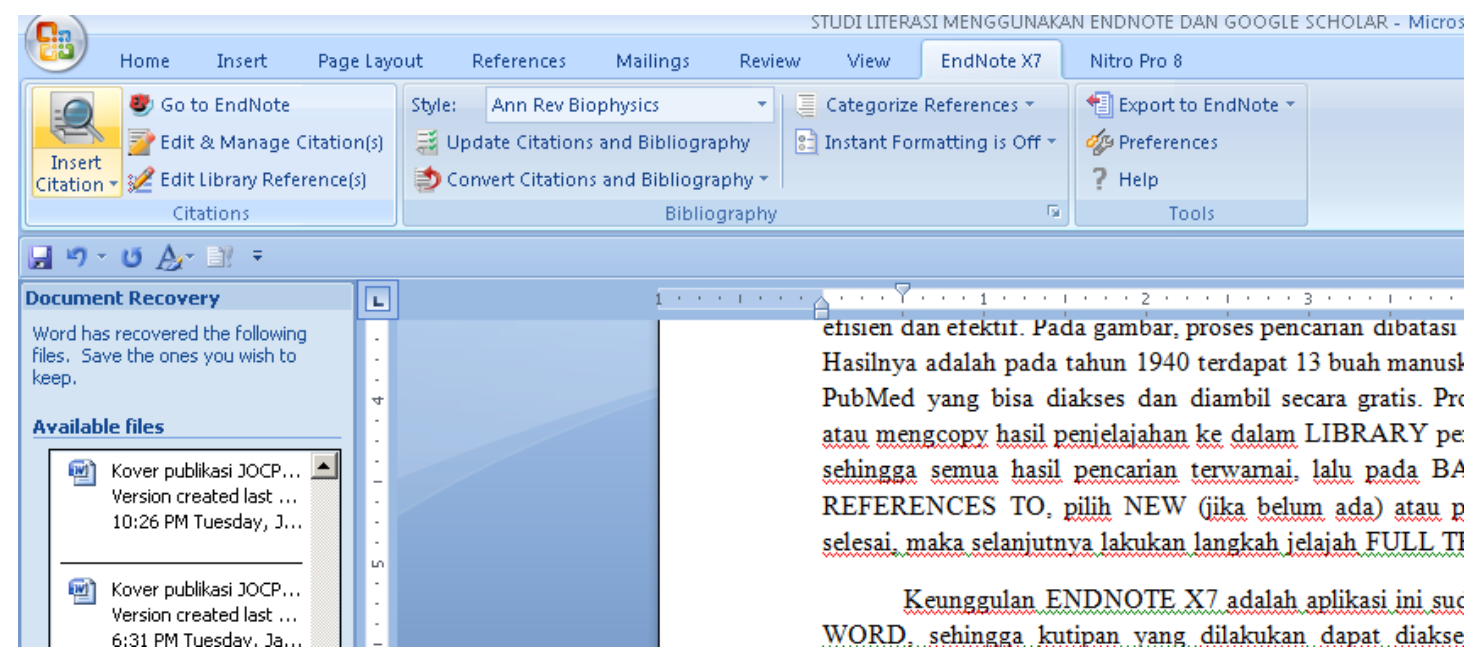

Gambar 9. BAR endnote yang telah diaktifkan pada WORKSPACE MicrosoftWord

Proses literasi selesai apabila penyempurnaan dilakukan dengan menggunakan aplikasi pelengkap pembantu yang telah tersedia. Misalnya, google translator untuk penterjemahan literasi, CambridgeSoft untuk display mikroskopik dan simbolik, NITRO 8 untuk konversi dan pengolahan alfabetis, dan snipping tool untuk image dan cuplikan gambar secara cepat dan praktis.

Proses proses aplikasi pelengkap dapat dilakukan dengan melakukan latihan membuat satu topic bahasan atau kajian ilmiah. Pertama, lakukan pilihan tema, dan buat idea tau gagasan menjadi beberapa kalimat, serta tentukan keyword yang akan dilakukan penelusuran. Setelah itu, proses pengumpulan dan ekplorasi literaratur dilakukan, baik literature berbahasa inggris maupun Indonesia. Namun, karena proses dilakukan secara internasional dan di perpustakaan dunia, maka umumnya naskah yang diperoleh adalah naskah dalam bahasa inggris.

Pada pengolahan data atau literature, peranan aplikasi pembantu sangat dominan, salah satunya adalah Nitro 8 yang berfungsi melakukan konversi PDF menjadi word. Setelah itu, lakukan formatting dan editing sebelum melakukan translating pada Google Translator. Apabila proses formatting dan editing awal atau CLEAN MISSROUTE atau Kesalahan posisi dokumen, baik kata dan kalimat serta tanda baca, maka proses selanjutnya akan keliru. Apabila diperlukan FIND and REPLACE bisa membantu. Setelah semua DOKUMEN KONVERSI selesai dibersihkan, maka lanjutkan dengan translating dan editing. Proses ini memerlukan latihan dan pengulangan, agar didapat pemahaman yang benar dari proses penterjemahan. Sebab, Google Translator bersifat umum, sementara bahan literasi yang akan dipahami lebih spesifik. 
Penggunaan E-Learning dan aplikasi lainnya, adalah kemampuan atau skill computer yang tidak sulit, jika kemampuan literasi sudah dipahami dan dilatih. Pada bagian lanjutan adalah konversi WORD to PDF juga diperlukan pada tugas tugas yang harus dikirimkan pada elearning dari mata kuliah yang dipilih pada setiap semester. Penggunaan e-learning secara spesifik menggunakan data Username dan Password yang sesuai dengan nomor identitas NIM yang passwordnya bisa disesuaikan setelah mengakses perubahan password secara personal.

\section{KESIMPULAN}

Mahasiswa Baru Program Studi Pendidikan IPA FMIPA UNP dapat menggunakan endnote X7 untuk mengembangkan kemampuan atau skill literasi sesuai dengan perkembangan sains dan teknologi. Dengan keahlian dalam penggunaan software dan aplikasi ini, kemajuan teknologi dapat dioptimalkan untuk menyelesaikan tugas tugas perkuliahan dan membantu menyusun literasi pada tugas akhir.

\section{REFERENCES}

1. Aalai E, Gleghorn C, Webb A, Glover SW. 2009. Health information and libraries journal 26:56-62

2. Altman SH, Shactman D. 1997. The New England journal of medicine 337:1778-9

3. Bramer WM, Giustini D, de Jonge GB, Holland L, Bekhuis T. 2016. Journal of the Medical Library Association : JMLA 104:240-3

4. Cantor WJ, Brunet F, Ziegler CP, Kiss A, Morrison LJ. 2005. CMAJ : Canadian Medical Association journal = journal de l'Association medicale canadienne 173:1473-81

5. Brooke-Sumner C, Petersen I, Asher L, Mall S, Egbe CO, Lund C. 2015. BMC psychiatry 15:19

6. Escobedo AA, Arencibia R, Vega RL, Rodriguez-Morales AJ, Almirall P, Alfonso M. 2015. Journal of infection in developing countries 9:76-86

7. Einollahi B, Motalebi M, Taghipour M, Ebrahimi M. 2015. Nephro-urology monthly 7:e30911

8. Li Y, Wen J, Du L, Gao Z, Li L, et al. 2009. Journal of evidence-based medicine 2:252-7

9. Jiang Y, Lin C, Meng W, Yu C, Cohen AM, Smalheiser NR. 2014. Database : the journal of biological databases and curation 2014:bat086

10. Lorenzetti DL, Ghali WA. 2013. BMC medical research methodology 13:141

11. Nawafleh N, Hatamleh M, Elshiyab S, Mack F. 2016. Journal of prosthodontics : official journal of the American College of Prosthodontists 25:116-26

12. Ong ME, Mackey KE, Zhang ZC, Tanaka H, Ma MH, et al. 2012. Scandinavian journal of trauma, resuscitation and emergency medicine 20:39

13. Liu X, Wu J, Wang J, Liu X, Zhao S, et al. 2009. Nucleic acids research 37:W33-9

14. Ng L, Pitt V, Huckvale K, Clavisi O, Turner T, et al. 2014. Systematic reviews 3:121

15. Rathbone J, Carter M, Hoffmann T, Glasziou P. 2015. Systematic reviews 4:6

16. Roura M, Domingo A, Leyva-Moral JM, Pool R. 2015. BMC public health 15:472

17. Shayo A, Buza J, Ishengoma DS. 2015. Malaria journal 14:135 
18. van der Heijden E, Lopes AD, Bryant A, Bekkers R, Galaal K. 2015. The Cochrane database of systematic reviews 1:CD010757

19. Verbitskaya EV. 2015. The International journal of risk \& safety in medicine 27 Suppl 1:S89-90

20. Wei M, He Y, Wang J, Chen N, Zhou Z, Wang Z. 2014. PloS one 9:e87461

21. Wickramasinghe DP, Perera CS, Senarathna S, Samarasekera DN. 2013. BMC medical education 13:175

22. Younger P, Boddy K. 2009. Health information and libraries journal 26:126-35 